\section{Mentoring for Inclusion: The Impact of Mentoring on Undergraduate Researchers in the Sciences}

\author{
Heather Haeger* and Carla Fresquez \\ Undergraduate Research Opportunities Center (UROC), California State University, Monterey Bay, \\ Seaside, CA 93955
}

\begin{abstract}
Increasing inclusion of underrepresented minority and first-generation students in mentored research experiences both increases diversity in the life sciences research community and prepares students for successful careers in these fields. However, analyses of the impact of mentoring approaches on specific student gains are limited. This study addresses the impact of mentoring strategies within research experiences on broadening access to the life sciences by examining both how these experiences impacted student success and how the quality of mentorship affected the development of research and academic skills for a diverse population of students at a public, minority-serving institution. Institutional data on student grades and graduation rates $(n=348)$ along with postresearch experience surveys ( $n=138$ ) found that students mentored in research had significantly higher cumulative grade point averages and similar graduation rates as a matched set of peers. Examination of the relationships between student-reported gains and mentoring strategies demonstrated that socioemotional and culturally relevant mentoring impacted student development during mentored research experiences. Additionally, extended engagement in research yielded significantly higher development of research-related skills and level of independence in research. Recommendations are provided for using mentoring to support traditionally underrepresented students in the sciences.
\end{abstract}

Lack of diversity in graduate programs, especially at selective institutions and in science, technology, engineering, and mathematics (STEM) fields is one of many problems that lead to diversity issues in STEM professions and equity issues for students. Simultaneously, participation in research at the undergraduate level has become an increasingly required activity in order to gain access to merit-based scholarships and awards, acceptance into graduate school, and competitive career opportunities. Increasingly, however, the inclusion of underrepresented minority (URM) and first-generation students in faculty-mentored undergraduate research (UR) opportunities has been recognized as a significant step toward resolving these issues and increasing diversity in graduate education, STEM fields, and the research community.

Research has lauded the inclusion of research experiences for undergraduate students and illustrated the benefits of these activities (Bauer and Bennett, 2003; Kuh et al., 2010; Laursen, 2010). Unfortunately, the bulk of this research relies on data from predominantly white institutions (PWIs) and overrepresents the experiences of traditionally privileged college students. However, notable exceptions to this majority have begun to take a more inclusive look at participation in research, illustrating that URM and first-generation students benefit significantly more than other students from participating in research (Cole and Espinoza, 2008; Hurtado et al., 2008; Kinzie et al., 2008; Jones et al., 2010; Finley and McNair, 2013). This study will address how mentored research experiences may broaden access to life sciences for a diverse population of student researchers by examining how these experiences and the various mentorship
Pat Marsteller, Monitoring Editor Submitted January 16, 2016; Revised May 31, 2016; Accepted June 17, 2016

CBE Life Sci Educ September 1, 2016 15:ar36 DOI:10.1187/cbe.16-01-0016

*Address correspondence to: Heather Haeger (hhaeger@csumb.edu).

๑) 2016 H. Haeger and C. Fresquez. CBE-Life Sciences Education @ 2016 The American Society for Cell Biology. This article is distributed by The American Society for Cell Biology under license from the author(s). It is available to the public under an Attribution-Noncommercial-Share Alike 3.0 Unported Creative Commons License (http://creativecommons.org/licenses/ by-nc-sa/3.0).

"ASCB®" and "The American Society for Cell Biology $\circledR^{\prime}$ are registered trademarks of The American Society for Cell Biology. 
practices associated with these experiences affect student success outcomes, foster the development of research and academic skills, and impact the quality of the UR experience. The specific research questions addressed are as follows:

1. What is the impact of participating in a mentored research experience on student success as measured by senior year cumulative grade point average (GPA) and 6-year graduation rates?

2. What factors in the student-mentor relationship impact student development?

a. What types of mentoring (skill-based/instrumental mentoring, socioemotional mentoring, and/or culturally relevant mentoring) are related to student development of research-related skills, academic and professional development, and level of independence in research?

b. Does the amount of time in a mentored research experience affect the development of research-related skills, academic and professional development, and level of independence in research?

\section{CONCEPTUAL FRAMEWORK \\ Benefits of Research}

Undergraduate participation in research as a high-impact practice has been linked to a number of measures of student success (Kuh et al., 2010). Research participation is related to overall student engagement (Kinzie et al., 2008; Kuh et al., 2010) and increased deep learning, practical experiences, and hands-on learning opportunities (Hunter et al., 2007; Laursen et al., 2012). UR has also been demonstrated to improve academic success, retention, and persistence in STEM fields (Russell et al., 2007; Crawford, 2008; Jones et al., 2010). The timing and duration of UR are also important. Earlier participation in research and research experiences that persist longer than one term increased the impact on retention and academic performance for underrepresented students (Jones et al., 2010) and increased the benefits of UR for all students (Bauer and Bennett, 2003).

\section{Underrepresentation in STEM and Research}

Though UR can benefit students across disciplines (Kuh et al., 2010), engaging a diverse pool of students in research is particularly beneficial for training and retaining traditionally underrepresented students in STEM (Cole and Espinoza, 2008; Hurtado et al., 2008; Jones et al., 2010; Finley and McNair, 2013). Currently, URM and first-generation students enter postsecondary STEM programs at lower rates (Huang et al., 2000) and are less likely to complete college when they initially enroll in a STEM major (Higher Education Research Institute, 2010). Often touted as a crisis, this lack of prepared undergraduate students, in particular URM students, graduating from STEM fields is cause for concern for the national economy and the advancement of these fields (National Math + Science, 2010).

Underrepresented students who participate in research are more likely to remain in their field and maintain their career goals (Schultz et al., 2011). Research participation is particularly impactful on student retention and success for students of color, students who are less academically prepared, first-generation students, and low-income students in STEM (Lopatto, 2007; Cole and Espinoza, 2008; Jones et al., 2010). Participat- ing in research has demonstrated a compensatory effect for first-generation, low-income, and URM students in that these students benefit even more from UR participation and this participation can, at least partially, compensate for disadvantages these students may face (Kinzie et al., 2008; Finley and McNair, 2013).

The benefits of UR for all students and the additional benefits of UR for preparing and retaining a diverse pool of students in STEM are well documented. However, the factors that influence the quality of UR experienced by a diverse population of students are less well explored. In addition to quantifying the overall impacts on student outcomes, this research attempts to quantify the factors that foster the development of research and academic skills in students and impact the quality of the UR experience; factors that may ultimately lead to broadened access for URM individuals to careers in STEM fields.

\section{METHODS}

To allow for a nuanced look at the experiences of underrepresented students and students in diverse environments, we used survey and qualitative data from students participating in UR at California State University, Monterey (CSUMB), a public minority-serving institution (MSI). This institution was chosen due both to its diverse student body and its high rates of participation in UR. Of the students who participate in research at CSUMB, 44\% are low income, 53\% are from a traditionally URM, and 65\% are the first in their family to go to college. Two sources of data are used to explore both the impact of mentoring students in research and aspects of mentoring that shape students experiences: institutional data on student success and postresearch survey data on students' experiences in mentored research.

\section{Institutional Data on Student Success}

Institutional data collected from all CSUMB students from 2008 through 2014 were used to create matched data sets of students in mentored research and a control group of students. Propensity score matching was used to create a control group that matched the treatment group (students who participated in mentored research; see Figure 1 for conceptual model). Variables were chosen based on previous literature that suggests that socioeconomic status (SES), enrollment status, age, gender, and ethnicity are all related to the likelihood of participating in mentored research (Haeger et al., 2016). In addition, a criticism of previous studies that have found positive relationships between UR and student success has been that high-achieving students were more likely to be involved in research and previous studies did not adequately control for prior academic performance or aptitude (Gonyea and Miller, 2011). For this reason, the sample was also matched on academic performance before enrolling in the university in order to measure academic performance before participation in mentored research. See the Supplemental Material for more information on the creation of the matched sample and a comparison of the matched set with the overall student population.

A logistic model was used to compute the probability of participating in mentored research based on prior academic performance (high school GPA for institution native students and transfer GPA for transfer students), age, gender, full-time enrollment status, SES (defined as Pell Grant eligibility), and 


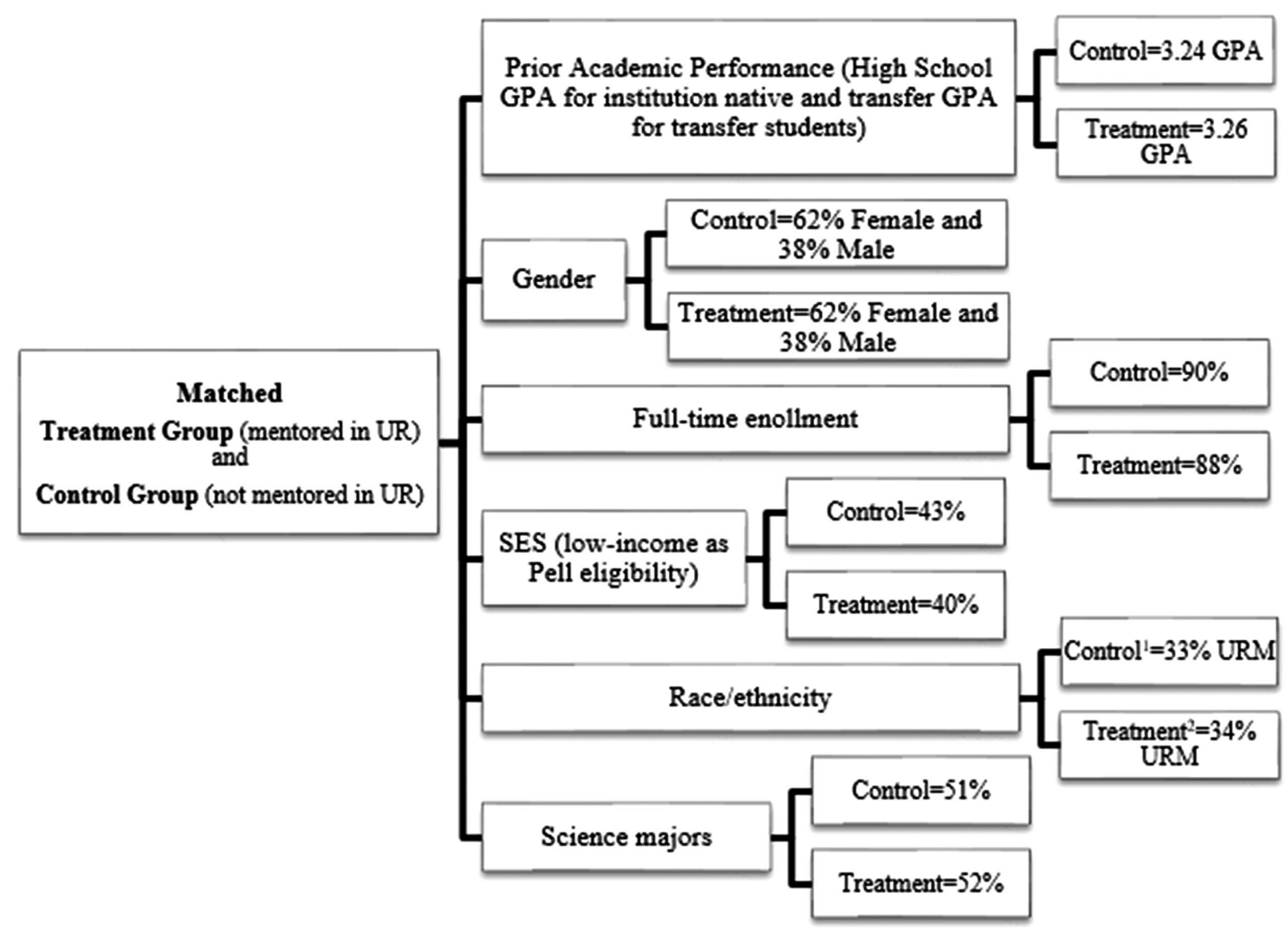

FIGURE 1. Conceptual model for propensity score matching. ${ }^{1}$ Control $=4 \%$ African American/black, $11 \%$ Asian American, $22 \%$ Latino, $3 \%$ Pacific Islander, $4 \%$ multiracial, $52 \%$ white, $4 \%$ other/declined to answer. ${ }^{2}$ Treatment $=4 \%$ African American/black, $9 \%$ Asian American, 25\% Latino, 2\% Pacific Islander, 3\% multiracial, 53\% white, 5\% other/declined to answer. (See the Supplemental Material for more details on the creation of matched data sets.)

race/ethnicity (Figure 1). Students in the treatment group were matched with a student from the control group based on the probability estimate (difference in probability estimate $<0.001$ ). The matched sample includes 174 students in the treatment group and 174 students in the control group. Regressions controlling for student characteristics and prior academic performance were conducted on this matched set of students to analyze differences in student success, including graduating GPA, time to degree, and graduation rates. A linear regression was conducted on graduating GPA, and a logistic regression was conducted on graduation rates.

\section{Survey Data on Experiences in Mentored Research}

In addition to data on student success, surveys on the mentored research experience and its impact on student development were also conducted to examine aspects of the research experience that impact student development, including different types of mentoring provided by faculty and the length of time the student engaged in mentored research. These data were separate from the institutional data described previously and were collected in the Fall of 2012 and the Fall of 2013, after students had completed a summer research experience. Though self-reported data have been criticized for being closely related to satisfaction and are not a direct measure of content knowl- edge (Pike, 2011), we believe that examination of what students think they are learning and what skills they think they are developing is, in addition to looking at academic outcomes, an important feature to analyze. Additionally, self-reported data are essential in measuring the nuances that define a successful, high-quality mentored UR experience, including the type of support provided by a mentor. Recent research has demonstrated the validity of using self-reported data and, specifically, self-reported gains when used appropriately (Gonyea and Miller, 2011). Self-reported learning should be used as a measure of perceived learning and subjective outcomes. For this reason, the present study combines academic success data (GPA and graduation rates) with data from a postmentored research survey about the research experience (perceived learning, and types of mentor support). To further test the validity of the self-reported data included in this study, we compared student scores with mentors' ratings of students on the same items. No significant differences were found between student's self-appraisals of their development and their mentors' assessments, though students gave themselves slightly lower than those assigned by their mentors (Haeger et al., 2015).

The sample from the survey data includes 138 students who completed their research experiences and the survey: five sophomores, 38 juniors, and 95 seniors. Of the students who 
TABLE 1. Student outcome scales: student development

\begin{tabular}{|c|c|c|}
\hline Scale & Survey items & $\begin{array}{l}\text { Cronbach's } \\
\text { alpha }\end{array}$ \\
\hline $\begin{array}{l}\text { Research-specific } \\
\text { gains }\end{array}$ & $\begin{array}{l}\text { How has your research experience contributed to the following...? } 1 \text { not at all, } 2=\text { a small amount ... } 5=\text { a great } \\
\text { deal } \\
\text { Knowledge of ethical conduct in your research field } \\
\text { Understanding of how researchers think and conduct their work } \\
\text { Ability to read and understand primary literature in your field } \\
\text { Ability to deal with frustrations and the "trial and error" in the research process } \\
\text { Skill in independently developing a research question } \\
\text { Skill in developing a research methodology } \\
\text { Technical research skills and/or laboratory techniques (e.g., instruments, tools, and other research techniques) } \\
\text { Skill in interpreting research results } \\
\text { Skill in relating research results and explanations to the work of others } \\
\text { Ability to contribute your skills and knowledge to a research team } \\
\text { Skill in communicating research results in a written format (e.g., abstract or paper) } \\
\text { Skill in communicating research results in an oral presentation }\end{array}$ & 0.91 \\
\hline $\begin{array}{l}\text { Professional and } \\
\text { academic gains }\end{array}$ & $\begin{array}{l}\text { How has your research experience contributed to the following ...? } 1 \text { = not at all, } 2=\text { a small degree ... } 5=\text { a very } \\
\quad \text { large degree } \\
\text { Ability to build professional networks } \\
\text { How self-sufficient you feel in your academic pursuits (e.g., identifying courses, finding resources and } \\
\quad \text { opportunities) } \\
\text { How prepared you feel now for graduate school } \\
\text { Confidence in your career decision-making skills } \\
\text { Feeling of "fit" between your goals and a career related to your current research }\end{array}$ & 0.83 \\
\hline $\begin{array}{l}\text { Research } \\
\quad \text { involvement }\end{array}$ & $\begin{array}{l}\text { Please rate your level of satisfaction with } \ldots ? 1=\text { very dissatisfied } \ldots 5=\text { very satisfied } \\
\text { Your level of involvement in research and/or lab team meetings } \\
\text { Your experiences working on a research project } \\
\text { Your research placement } \\
\text { The results of your project } \\
\text { Writing your research proposal }\end{array}$ & 0.93 \\
\hline
\end{tabular}

participated in a mentored research experience, 38\% were from a URM, 39\% were low income (Pell Grant eligible), and about half were first-generation college students. Students were asked about both their experiences in research and relationships with their mentors and what they learned or gained from the experience. Principal components analysis (see the Supplemental Material for details on scale development) with a varimax rotation was used to reduce the data and develop scales to measure closely related sets of outcomes; research-specific gains, professional and academic gains, and research involvement (see Table 1). From the factor loadings, scales were created conceptually by grouping survey items based on specific skills. Scales were tested through an examination of collinearity and reliability. The student's self-reported development on each item in the scale was averaged to yield a single score measuring that area.

Scales measuring the quality of the relationship between mentor and student were also created to measure how various mentoring approaches-instrumental mentoring, socioemotional mentoring, and culturally relevant mentoring - relate to a student's development of research and academic skills (Table 2).

Correlations between the types of mentoring and student outcomes were used to explore students' relationships with their research mentors. Qualitative analysis of students' written responses about barriers and challenges they faced in their research was also coded, analyzed, and compared with the survey measures. Mean comparisons were also conducted between students who had a one-term (summer or semester) mentored research experience and students who had a prolonged (more than one term) mentored research experience to explore the impact of length of time being mentored on student development.

\section{LIMITATIONS}

Though this study uses data from various sources to explore multiple facets of mentored research, each data source had its limitations. While the institutional data included the entire population of CSUMB students, they were still limited to students from a single institution. Despite this limitation, analysis of these data provided a unique contribution, since the institution used was a small, public, MSI in contrast to the large PWIs represented in other studies. These data also had the limitation of only providing basic information about students. The ability to match on less tangible student characteristics like intrinsic and extrinsic motivation, campus engagement, and educational aspirations would have strengthened the matching model, but those types of data were not available. The institutional data were largely complete, but a small proportion of student records were missing parental education or preenrollment GPA. Only records with whole matched pairs from the propensity score matching were included in the analysis. The survey data used included more detailed measures of students' motivations and experiences, but were limited as self-reported data and by a small sample size. These data are still included to explore the nuances within the research experience, and both effect size 
TABLE 2. Mentoring scales: mentoring strategies and approaches

\begin{tabular}{|c|c|c|}
\hline Scale & Survey items & $\begin{array}{c}\text { Cronbach's } \\
\text { alpha }\end{array}$ \\
\hline $\begin{array}{l}\text { Instrumental } \\
\text { mentoring }\end{array}$ & $\begin{array}{l}\text { To what extent did your research mentor ...? } \\
1 \text { = not at all, } 2 \text { = slightly ...5 = a great deal } \\
\text { Give you a challenging research assignment/project that presented opportunities for you to learn new research and } \\
\text { professional skills } \\
\text { Help you figure out for yourself how to focus your research question } \\
\text { Help you figure out for yourself how to carry out the steps in your research } \\
\text { Help you master the skills, methods, and/or techniques to conduct your research } \\
\text { Help you figure out how to explain your research findings to others } \\
\text { Help you finish tasks and meet deadlines that would have been otherwise difficult to complete }\end{array}$ & 0.93 \\
\hline $\begin{array}{l}\text { Socioemotional } \\
\text { mentoring }\end{array}$ & $\begin{array}{l}\text { To what extent did your research mentor ...? } \\
1 \text { = not at all, } 2 \text { = slightly ... } 5=\text { a great deal } \\
\text { Act warm and friendly to you } \\
\text { Show concern for your feelings } \\
\text { Demonstrate good listening skills during your conversations } \\
\text { Serve as a positive role model in her/his profession } \\
\text { Help you feel welcome and comfortable during your research experience }\end{array}$ & 0.91 \\
\hline $\begin{array}{l}\text { Culturally } \\
\text { relevant } \\
\text { mentoring }\end{array}$ & $\begin{array}{l}\text { To what extent did your research mentor ...? } \\
1 \text { = not at all, } 2 \text { = slightly ... } 5 \text { = a great deal } \\
\text { Understand how your background (e.g., ethnicity, gender, social class) contributes to your experience of being a } \\
\quad \text { student } \\
\text { Spend time getting to know you, your background, and your goals at the beginning of your research experience } \\
\text { Closely relate to your personal background (e.g., ethnicity, gender, social class) }\end{array}$ & 0.81 \\
\hline
\end{tabular}

and statistical significance were computed. These data were also used to compare students who participated in a one-term research experience with students who participated in research for more than one term. This sample is useful because students are in the same program and receiving the same support, but it is also limited because the students who only participate in one term of research may be inherently different from students who participate for longer periods of time. Approximately one-third of the students in the one-term group went on to continue participating in research after the data were collected, suggesting that they are more similar to the more-than-one-term group. The rest of the sample only completed one term of research out of choice or because of other considerations, including not having more time before graduation. These data do not allow us to control for student characteristics or levels of motivation, which might be dissimilar between these groups.

\section{FINDINGS}

\section{Student Outcomes}

Based on the matched set of students who participated in mentored UR and a control group of students who did not participate in mentored UR, students who participated in mentored UR had a significantly higher cumulative GPA by their senior year than similar peers, with the linear regression model explaining 39\% of the variance in GPA (see Table 3). The absolute difference in GPA was slight (3.41 cumulative GPA of students mentored in research compared with 3.34 in the control group). Unsurprisingly, prior academic performance was also a strong predictor of graduating GPA. STEM majors graduated with significantly lower GPAs than their non-STEM peers.
Though our results indicated that UR students did not graduate sooner than similar peers, they also indicate that students did not take significantly longer to graduate (no significant difference in 6-year or lower graduation rates), suggesting that the extra time and effort devoted to research did not impede their time to graduation (see Table 3). Though no comparison data were available on postgraduate outcomes, a subgroup of students included in the UR group $(n=11)$ who participated in a structured, 2-year mentoring relationship with faculty all applied to graduate school. Ten out of these 11 students were accepted to at least one graduate program with funding in the form of assistantships, grants, and/or fellowships.

These findings on student outcomes suggest that participating in mentored research opportunities is beneficial to students but do not distinguish between factors that impact the quality of the UR.

\section{Quality of Mentored Research Experiences}

The data from post-UR experience surveys illustrate the importance of the relationship between the mentor and student (Table 4).

Mentors providing instrumental mentoring, socioemotional mentoring, and culturally relevant mentoring yielded significant research-specific gains, academic and professional gains, and greater student research involvement. Socioemotional and culturally relevant mentoring correlated strongly with refinement of students' academic and career goals $(r=0.47, p<0.01$, and $r=0.31, p<0.01$, respectively), reporting an overall positive relationship with their mentor $(r=0.69, p<0.01$, and $r=$ $0.45, p<0.01$, respectively), and their overall level of satisfaction with research experiences $(r=0.41, p<0.01$, and $r=0.25$, 
TABLE 3. The impact of mentored research on GPA and graduation $(n=261)$

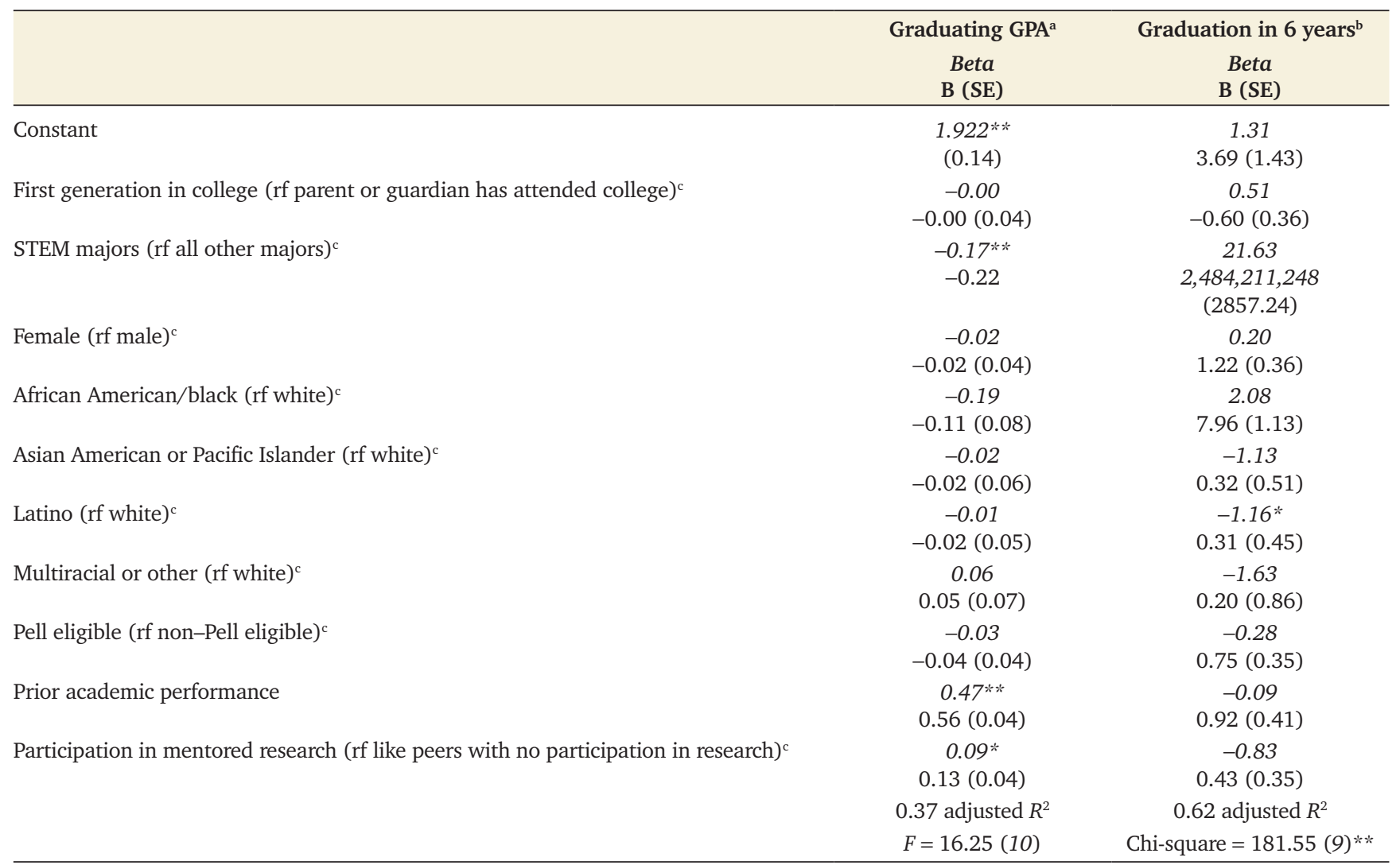

\footnotetext{
Linear regression.

bogistic regression.

${ }^{c} \mathrm{rf}=$ reference group.

$* p<0.01$.

$* * p<0.001$.
}

$p<0.01$, respectively). Instrumental mentoring, characterized by modeling or training in research-specific skills, was most strongly related to research skill development (research-specific gains; $r=0.57, p<0.01$ ), academic gains (professional and academic gains; $r=0.32, p<0.01$ ), and independence in research (research involvement; $r=0.61, p<0.01$ ).

Qualitative analysis of responses from students who felt least supported by their mentors illustrated that miscommunication

TABLE 4. Correlations between mentoring strategies and research skill development

\begin{tabular}{|c|c|c|c|}
\hline & $\begin{array}{c}\text { Culturally relevant } \\
\text { mentoring }\end{array}$ & $\begin{array}{c}\text { Instrumental } \\
\text { mentoring }\end{array}$ & $\begin{array}{c}\text { Socioemotional } \\
\text { mentoring }\end{array}$ \\
\hline Culturally relevant mentoring & 1 & $0.365^{* *}$ & $0.620^{* *}$ \\
\hline Instrumental mentoring & $0.365^{* *}$ & 1 & $0.506^{* *}$ \\
\hline Socioemotional mentoring & $0.620^{* * *}$ & $0.506^{* *}$ & 1 \\
\hline Research-specific gains & $0.211^{*}$ & $0.574^{* *}$ & $0.219 *$ \\
\hline Professional and academic gains & $0.238^{* *}$ & $0.321^{* *}$ & $0.227^{* *}$ \\
\hline The amount of time spent doing meaningful research & $0.300^{* *}$ & $0.582^{* *}$ & $0.454^{* *}$ \\
\hline Had a positive and productive relationship with mentor and research group & $0.450^{* *}$ & $0.583^{* *}$ & $0.689^{* *}$ \\
\hline Refined academic and career goals as a result of research experience & $0.312^{* *}$ & $0.443^{* * *}$ & $0.472^{* *}$ \\
\hline Feel more competent as a researcher & $0.293^{* * *}$ & $0.506^{* *}$ & $0.431^{* *}$ \\
\hline Became more committed to going to graduate school and completing an advanced degree & $0.282^{* *}$ & $0.269^{* * *}$ & $0.304^{* *}$ \\
\hline
\end{tabular}

*Correlation is significant at the 0.05 level (two-tailed).

** Correlation is significant at the 0.01 level (two-tailed). 
TABLE 5. Length of time in research: student outcome scales

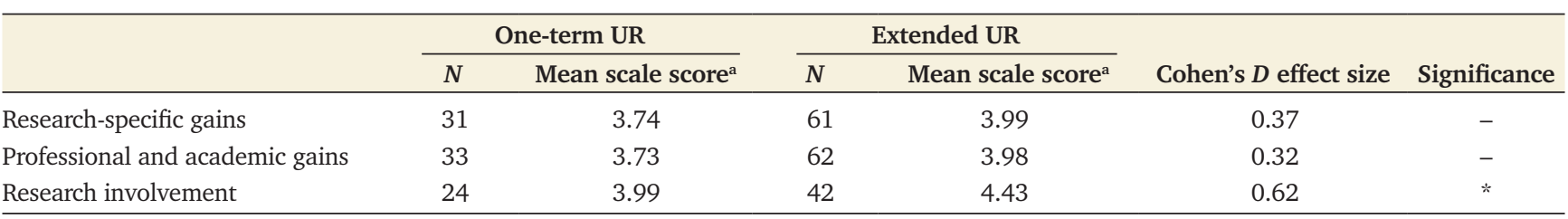

${ }^{a}$ Mean gains score: 1 = low; 5 = high.

$* p<0.05$.

was a common cause of conflict. In addition to rating their mentors as less culturally relevant, these students had problems communicating with their mentors due to differences in communication styles or misunderstanding the tone or humor their mentors used (e.g., "I did not enjoy communicating with her. There were times where I couldn't tell if she was just going out of her own way to be mean or if I just didn't understand her sense of humor."). Other students who rated their mentor lower on the culturally relevant mentorship and socioemotional scales also reported that their faculty were less available to meet with them, worked less collaboratively with them, and were less responsive to their needs and questions. In contrast, students who rated their mentors higher in culturally relevant mentorship also discussed feeling more connected to their fields of study and professions from working with their mentors; this including feeling a "sense of belonging in the research world."

\section{Duration of Mentored Research Experiences}

In addition to reporting higher-quality mentoring relationships, students who spent a sustained amount of time working with their mentors on research (more than one term or summer) reported significantly higher confidence across several of the measured gains scales, including in their research skills, independence, and understanding of the research process (see Tables 5 and 6). Students who had prolonged exposure to mentored research scored higher in all three research and academic skill development gains scales, with significant differences in the development of research-specific skills (research-specific gains; $t=-1.66, d f=90, p<0.10, d=0.37$ ) and the students'

TABLE 6. Length of time in research: individual items

\begin{tabular}{|c|c|c|c|c|c|c|}
\hline & \multicolumn{2}{|r|}{ One-term UR } & \multicolumn{2}{|r|}{ Extended UR } & \multirow[b]{2}{*}{ Cohen's $D$ effect size } & \multirow[b]{2}{*}{ Significance } \\
\hline & $N$ & Mean gains score ${ }^{a}$ & $N$ & Mean gains score ${ }^{a}$ & & \\
\hline $\begin{array}{l}\text { Gains in understanding of how researchers think } \\
\text { and conduct their work }\end{array}$ & 33 & 3.94 & 62 & 4.39 & 0.51 & $*$ \\
\hline $\begin{array}{l}\text { Gains in ability to deal with frustrations and the } \\
\text { "trial and error" in the research process }\end{array}$ & 33 & 3.97 & 62 & 4.42 & 0.51 & $*$ \\
\hline $\begin{array}{l}\text { Gains in technical research skills and/or } \\
\text { laboratory techniques (e.g., instruments, } \\
\text { tools, and other research techniques) }\end{array}$ & 33 & 3.67 & 62 & 4.27 & 0.51 & $*$ \\
\hline Gains in skill in interpreting research results & 33 & 3.03 & 62 & 3.65 & 0.49 & $*$ \\
\hline $\begin{array}{l}\text { Gains in skill in relating research results and } \\
\text { explanations to the work of others }\end{array}$ & 33 & 3.06 & 62 & 3.90 & 0.67 & $* *$ \\
\hline $\begin{array}{l}\text { Confidence in ability to work in a rigorous } \\
\text { research environment }\end{array}$ & 33 & 3.88 & 62 & 4.27 & 0.43 & $*$ \\
\hline Gains in ability to work independently & 33 & 3.97 & 62 & 4.40 & 0.49 & $*$ \\
\hline $\begin{array}{l}\text { Mentors provided a challenging research } \\
\text { assignment/project that presented opportuni- } \\
\text { ties to learn new research and professional } \\
\text { skills. }\end{array}$ & 33 & 3.94 & 62 & 4.45 & 0.47 & $*$ \\
\hline $\begin{array}{l}\text { Mentors helped you figure out for yourself how } \\
\text { to focus your research question. }\end{array}$ & 33 & 3.21 & 62 & 3.77 & 0.36 & - \\
\hline $\begin{array}{l}\text { Satisfaction with the amount of time spent doing } \\
\text { meaningful science research }\end{array}$ & 33 & 4.00 & 62 & 4.50 & 0.53 & * \\
\hline $\begin{array}{l}\text { Confidence about ability to work effectively in a } \\
\text { professional environment }\end{array}$ & 33 & 4.21 & 62 & 4.53 & 0.48 & $*$ \\
\hline $\begin{array}{l}\text { As a result of your research, to what extent do } \\
\text { you feel you feel more competent as a } \\
\text { researcher in your field? }\end{array}$ & 33 & 4.00 & 62 & 4.40 & 0.46 & $*$ \\
\hline
\end{tabular}

Mean gains score: 1 = low; 5 = high.

${ }^{*} p<0.05$.

$* * p<0.01$. 
level of involvement and independence in research (research involvement; $t=-2.41, d f=64, p<0.05, d=0.62$ ).

When differences on individual survey items were examined, a similar pattern emerged of students who had extended mentoring in UR scoring higher in the development of research-related skills and level of involvement in research (Table 6). Additionally, students with prolonged mentoring in research were more confident about their abilities to work in research and professional environments $(t=-2.23, d f=93, p<$ $0.05, d=0.48)$, felt more competent as researchers in their fields $(t=-2.14, d f=93, p<0.05, d=0.54)$, and were more satisfied with the amount of time spent doing meaningful research $(t=-2.47, d f=93, p<0.05, d=0.53)$. Students who were mentored for more than one term also reported that their mentors were better able to help them develop challenging and rigorous research projects $(t=-2.19, d f=93, p<0.05, d=$ 0.47 ) and facilitated students developing and focusing their research questions $(t=-1.62, d f=93, p<0.05, d=0.36)$.

Qualitative analysis supports this finding, with students discussing the difference between their previous and current research experiences and feeling that they were better able to engage in meaningful research after having research experiences that lasted for longer than one term or having experience over multiple summers.

\section{IMPLICATIONS}

Mentored UR provides students with hands-on learning experiences that increase their academic success, as measured by cumulative GPA, and does not slow down time to degree for a diverse group of students. These findings are consistent with previous research suggesting UR boosts student learning and development in college (Russell et al., 2007; Crawford, 2008; Jones et al., 2010). Unfortunately, previous research also illustrates that URM, first-generation, and transfer students are less likely to engage in UR (Haeger et al., 2016). Further research is needed to explore the barriers that students face in engaging in UR and ways to engage more students in research in the sciences. Future research should also explore differences in the benefits of mentored research for students based on gender, race, and SES. Research on student engagement suggests that there is an even greater benefit for traditionally underrepresented students, but whether there is also a compensatory effect in academic success is still unclear (Kinzie et al., 2008; Finley and McNair, 2013; Haeger et al., 2015).

This research suggests that, in order to diversify the sciences, it is important to examine the relationships students build with research mentors. Previous research has suggested that mentors are more likely to engage in productive mentoring relationships with mentees they perceive as similar to themselves (Eby et al., 2000). Additionally, both mentors and mentees report that relationships were less rewarding when they had dissimilar beliefs, values, or interests, or when the mentor and mentee match was imposed by an outside agency as opposed to resulting from an organic relationship (Eby et al., 2000, 2004). These findings point to significant concerns for culturally, ethnically, and socioeconomically diverse students who are matched with mentors from a significantly less diverse faculty population. To increase representation of traditionally marginalized populations, we need to understand the types of support that mentors can provide to engage a diverse population of students and how they can overcome the barriers inherent in the current system. This research demonstrates the need for comprehensive mentoring that provides not only skills-based training but also socioemotional support and culturally relevant mentoring. Previous research has stressed the role of culturally relevant interactions with faculty as a dynamic exchange between students and educators that can affirm students' cultural identities and promote critical thinking through taking on different perspectives (Ladson-Billings, 1995; Lindsay-Dennis et al., 2011). This was true even when students and faculty did not come from the same background but were still able to foster a relationship built on mutual respect for the other person's experiences and perspectives. As colleges and universities work to engage more undergraduates in the sciences, training and support for faculty should facilitate the development of these mentoring skills.

This research also suggests that students from diverse backgrounds benefit from extended exposure to mentored UR. Owing to the small sample size, many of the differences were only moderately or marginally significant, though the actual difference and effect sizes were substantial. The overall trend across scales and individual items was that students who were mentored in research for more than one term experienced higher gains and more involvement in the research process. It is possible that more traditionally privileged students do not need an extended research experience and may gain as much from an 8- to 10-week UR experience as they would from an extended UR experience. In contrast, students who are being newly introduced to the academic and research culture, norms, and procedures clearly benefit from having a longer research experience and prolonged contact with a research mentor. The university student population from which our sample was drawn consists of largely traditionally underrepresented individuals, and many of these students come from underresourced school systems. This suggests that, in order to broaden participation of engaged scientific researchers from diverse backgrounds, institutions should seriously consider prolonged or multiple research experiences for students in addition to the traditional 8- to 10-week Research Experience for Undergraduates model. Further research should compare this finding with results from other institutions.

Unfortunately, current funding policies often favor funding first-time researchers and are less likely to support students in subsequent research opportunities. Though the intention of these policies is to provide opportunities to more students, they may also curtail traditionally underrepresented students exposure to mentored research. Funding agencies should consider how to balance the need to serve as many students as possible with the knowledge that multiple or prolonged research experiences also benefit students.

\section{CONCLUSION}

These findings demonstrate that participating in mentored research opportunities is beneficial to a diverse population of students in terms of academic performance and that the time and effort invested in mentored research do not diminish students' timely graduation rates. In addition to the general benefits of mentored research, a number of factors impacted how much students reported learning from these experiences. Students whose mentors provided socioemotional and culturally 
relevant mentoring along with research-specific mentoring reported stronger learning and development. In addition to the importance of the kinds of support mentors provided, the length of time working with their mentors on research also influenced student development during research experiences.

\section{REFERENCES}

Bauer KW, Bennett JS (2003). Alumni perceptions used to assess undergraduate research experience. J High Educ 74, 210-230.

Cole D, Espinoza A (2008). Examining the academic success of Latino stu dents in science technology engineering and mathematics (STEM) majors. J Coll Stud Dev 49, 285-300.

Crawford B (2008). Creating effective undergraduate research programs in science: the transformation from student to scientist. Sci Educ 9, 583585 .

Eby L, Butts M, Lockwood A, Simon SA (2004). Protégés negative mentoring experiences: construct development and nomological validation. Personnel Psychology 57, 411-447.

Eby LT, McManus SE, Simon SA, Russell JEA (2000). The protege's perspective regarding negative mentoring experiences: the development of a taxonomy. J Vocat Behav 57, 1-21.

Finley A, McNair T (2013). Assessing Underserved Students' Engagement in High-Impact Practices, Washington, DC: Association of American Colleges and Universities. www.aacu.org/assessinghips/documents/ TGGrantReport_FINAL_11_13_13.pdf (accessed 4 August 2016).

Gonyea RM, Miller A (2011). Clearing the AIR about the use of self-reported gains in institutional research. New Dir Inst Res 150, 99-111.

Haeger H, BrckaLorenz A, Webber K (2016). Participation in undergraduate research at minority serving institutions. Perspect Undergrad Res Mentoring 4(1). http://blogs.elon.edu/purm/files/2015/11/Haeger-et-al-PURM -4.1-1.pdf (accessed 4 August 2016).

Haeger H, Fresquez C, Clarkston B (2015). Mentee evaluation: structuring meaningful feedback from mentors to students and gathering data on what works. Presented at the Undergraduate Research Programs: Building, Enhancing, Sustaining Conference held June 23-25, 2015, in Norman, OK.

Higher Education Research Institute (2010). Degrees of Success: Bachelor's Degree Completion Rates among Initial STEM Majors, Los Angeles, CA www.heri.ucla.edu/nih/downloads/2010\%20-\%20Hurtado,\%20Eagan \%20Chang\%20-\%20Degrees\%20of\%20Success.pdf (accessed 8 August 2016)
Huang G, Taddese N, Walter E (2000). Entry and Persistence of Women and Minorities in College Science and Engineering Education (NCES 2000601), Washington, DC: U.S. Department of Education, National Center for Education Statistics. http://nces.ed.gov/pubs2000/2000601.pdf (accessed 8 August 2016).

Hunter AB, Laursen SL, Seymour E (2007). Becoming a scientist: the role of undergraduate research in students' cognitive, personal, and professional development. Sci Educ 91, 36-74.

Hurtado S, Eagan MK, Cabrera NL, Lin MH, Park J, Lopez M (2008). Training future scientists: predicting first-year minority student participation in health science research. Res High Educ 49, 126-152.

Jones MT, Barlow AEL, Villarejo M (2010). Importance of undergraduate research for minority persistence and achievement in biology. $\mathrm{J}$ High Educ 81, 82-115.

Kinzie J, Gonyea R, Shoup R, Kuh GD (2008). Promoting persistence and success of underrepresented students: lessons for teaching and learning New Dir Teach Learn 115, 21-38.

Kuh GD, Kinzie J, Schuh JH, Whitt EJ (2010). Student Success in College: Creating Conditions That Matter, 1st ed., ed. GD Kuh, San Francisco: Jossey-Bass

Ladson-Billings G (1995). Toward a theory of culturally relevant pedagogy Am Educ Res J 32, 465-491.

Laursen S (2010). Undergraduate Research in the Sciences: Engaging Students in Real Science, Hoboken, NJ: Wiley.

Laursen S, Seymour E, Hunter AB (2012). Learning, teaching and scholarship: fundamental tensions of undergraduate research. Change 44, 30-37.

Lindsay-Dennis L, Cummings L, McClendon SC (2011). Mentors' reflections on developing a culturally responsive mentoring initiative for urban African American girls. Black Women, Gender and Families 5, 66-92.

Lopatto D (2007). Undergraduate research experiences support science career decisions and active learning. CBE Life Sci Educ 6, 297-306.

National Math + Science (2010). Increasing the Achievement and Presence of Under-Represented Minorities in STEM Fields (White Paper). www nms.org/Portals/0/Docs/whitePaper/NACME\%20white\%20paper.pdf (accessed 8 August 2016).

Pike G (2011). Using college students' self-reported learning outcomes in scholarly research. New Dir Inst Res 150, 41-58.

Russell SH, Hancock MP, McCullough J (2007). Benefits of undergraduate research experiences. Science 316, 548-549.

Schultz PW, Hernandez PR, Woodcock A, Estrada M, Chance RC, Aguilar M, Serpe RT (2011). Patching the pipeline: reducing educational disparities in the sciences through minority training programs. Educ Eval Policy Anal $33,95-114$. 